\title{
Pathogen inactivation. New progress
}

\section{Antonio Piga}

Hemoglobinopathies Centre, Department of Clinical and Biological Sciences, University of Torino, Italy

\section{Oral presentation}

Oral presentation is available online

Correspondence: Antonio Piga

E-mail: antonio.piga@unito.it

(C) Copyright A. Piga, 2013

Licensee PAGEPress, Italy

Thalassemia Reports 2013; 3(s1):e24

doi:10.4081/thal.2013.s1.e24

This article is distributed under the terms of the Creative Commons Attribution Noncommercial License (by-nc 3.0) which permits any noncommercial use, distribution, and reproduction in any medium, provided the original author(s) and source are credited.

Parts of this work were presented at the

" $3^{\text {rd }}$ Pan-European Conference on Haemoglobinopathies and Rare Anaemias", Limassol (Cyprus), 24-26 October 2012. 